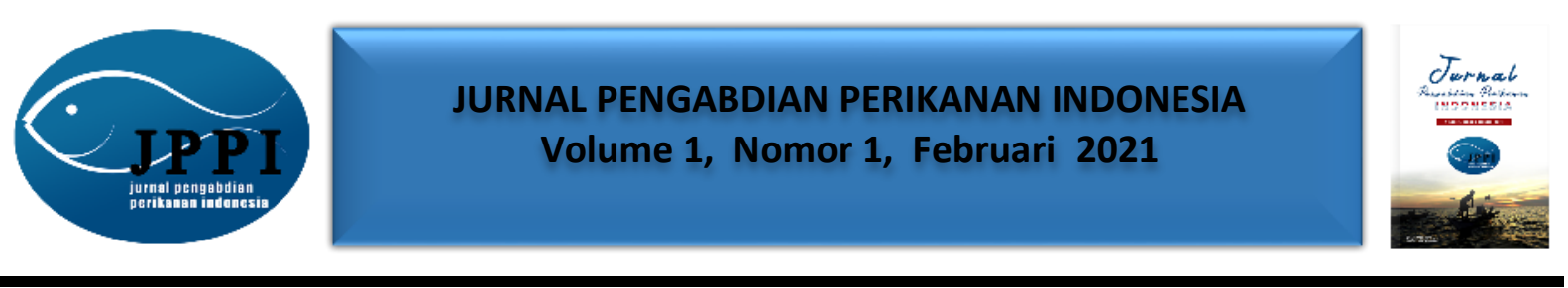

\title{
PROGRAM PENGABDIAN KEPADA MASYARAKAT TERINTEGRASI KKN TEMATIK DI TENGAH PENDEMI COVID-19 MELALUI BUDIDAYA IKAN AIR TAWAR DI KOMPLEKS PERUMAHAN
}

\author{
Sapto Raharjo ${ }^{1}$, Lina Lestari ${ }^{2}$, Adrian Rahmat Nur ${ }^{3}$ \\ ${ }^{1}$ Jurusan Kimia, Universitas Halu Oleo, Kendari Sulawesi Tenggara, ${ }^{2.3}$ Jurusan Fisika, Universitas Halu \\ Oleo, Kendari Sulawesi Tenggara
}

Kampus Hijau Bumi Tridharma, Anduonohu, Kec. Kambu, Kota Kendari, Sulawesi Tenggara 93232

Alamat korespondensi : saprjo@yahoo.com

(Tanggal Submission: 3 Desember 2020, Tanggal Accepted : 2 Februari 2021)

\begin{abstract}
Keyword: Abstrak :
KKN Pandemi Covid-19 masih menghantui Indonesia dan dunia, belum diketahui kapan akan Tematik, berakhir. Berbagai pelemahan aktivitas masyarakat dilakukan untuk mencegah UHO, penularan lebih lanjut. Di tengah kondisi tersebut, program Kuliah Kerja Nyata (KKN) Budidaya bagi mahasiswa Universitas Halu Oleo (UHO) harus terus dijalankan. Merujuk pada ikan protokol kesehatan, program pengabdian masyarakat terintegrasi KKN tematik telah dilaksanakan untuk periode semester genap 2019-2020. Ada dua tujuan, pertama, memperkenalkan bentuk-bentuk pemanfaatan sumber daya alam kepada peserta didik; kedua, memberikan contoh kepada masyarakat tentang budidaya ikan dengan Keramba Jaring Apung (KJA). Program KKN Tematik melibatkan dosen dari FMIPA, dan 30 (tiga puluh) mahasiswa dari berbagai program studi di UHO. Kegiatan ini berlangsung selama 2 (dua) bulan, Juni-Juli 2020. Tema yang dipilih adalah pemanfaatan sungai di Perumahan Taman Sari Kahyangan Kendari untuk budidaya ikan. Metode implementasinya adalah praktek langsung di lapangan dan sosialisasi kepada masyarakat. Pekerjaan di lapangan meliputi: pembuatan dua buah keramba masingmasing $3 \times 3 \times 3$ m3; penaburan benih Mujair dan Nila masing-masing 500 dan 250 ekor; dan memberi makan ikan 3 kali sehari selama 4 (empat) bulan. Penyuluhan tentang budidaya ikan air tawar ditujukan kepada petugas kebersihan perumahan. Selama mengikuti program, semua mahasiswa dapat menyelesaikan tugas dan tanggung jawabnya masing-masing. Diakhir kegiatan dilakukan pemanenan ikan, hasilnya diserahkan kepada petugas kebersihan.
\end{abstract}

Panduan Sitasi (APPA $7^{\text {th }}$ edition) :

Raharjo, S., Lestari, L., \& Nur, A.R. (2021). Program Pengabdian Kepada Masyarakat Terintegrasi Kkn Tematik Di Tengah Pendemi Covid-19 Melalui Budidaya Ikan Air Tawar Di Kompleks Perumahan. Jurnal Pengabdian Perikanan Indonesia, 1 (1), 77-80. http://doi.org/ 10.29303/jppi.v1i1.129 


\section{PENDAHULUAN}

Salah satu mata kuliah yang harus diambil oleh mahasiswa Universitas Halu Oleo (UHO) adalah Kuliah Kerja Nyata (KKN), Namun, untuk semester genap 2019/2020 kegiatan KKN tidak bisa dilaksanakan seperti semester-semester sebelumnya. Hal tersebut disebabkan oleh kondisi pendemi covid-19. Menyikapi hal ini, UHO mengambil kebijakan untuk tetap melaksanakan KKN dengan mengemasnya dalam program pengabdian dosen terintegrasi KKN tematik. Program KKN tematik kali ini sangat berbeda dengan sebelumnya mengingat pelaksanaanya harus mengikuti protokol kesehatan (prokes). Protokol kesehatan yang dimaksud meliputi: dilarang mengumpulkan mahasiswa secara bersama-sama, pembekalan dan pertemuan antara dosen dan mahasiswa dilakukan secara online, tidak diperkenankan membawa mahasiswa untuk tinggal di lokasi KKN.

Memperhatikan persyaratan KKN di atas maka penulis mengusulkan program pengabdian kepada masyarakat terintegrasi KKN tematik dengan tema "Budidaya ikan air tawar di sungai yang melintasi kompleks perumahan". Tujuan tema ini adalah: 1. Memanfaatan potensi sungai untuk menghasilkan nilai tambah secara ekonomi; 2 . Memberikan wawasan dan pengetahun budidaya ikan kepada mahasiswa dan petugas kebersihan.

Permasalahan yang muncul dikalangan masyarakat untuk memulai budidaya ikan air tawar antara lain adalah ketiadaan modal, dan kurangnya pengetahuan. Budidaya ikan air tawar di sungai dapat dilakukan salah satunya menggunakan Keramba Jaring Apung (KJA). Penggunaan KJA relatif sederhana dan mudah sehingga cocok diterapkan di sungai yang melintasi komplek perumahan.

\section{METODE KEGIATAN}

Program pengabdian terintegrasi KKN tematik melibatkan 3 (tiga) orang Dosen sebagai pembimbing lapangan, dan 30 (tga puluh) mahasiswa. Mahasiswa yang mengikuti program ini berasal dari program studi: Budidaya perikanan, Manajemen Sumber daya perikanan, Bioteknologi, Akuntansi, Psikologi, Biologi. Program ini berlangsung selama 2 (dua) bulan, Juni sampai Juli 2020.

Pelaksanaan kegiatan dibagai dalam tiga tahap, yaitu: (1). Persiapan, dilakukan pertemuan secara online melibatkan dosen dan seluruh mahasiswa peserta KKN. Tujuan pertemuan ini adalah untuk sosialisasi tema dan pembagian tugas kepada setiap mahasiswa (Gambar 1).

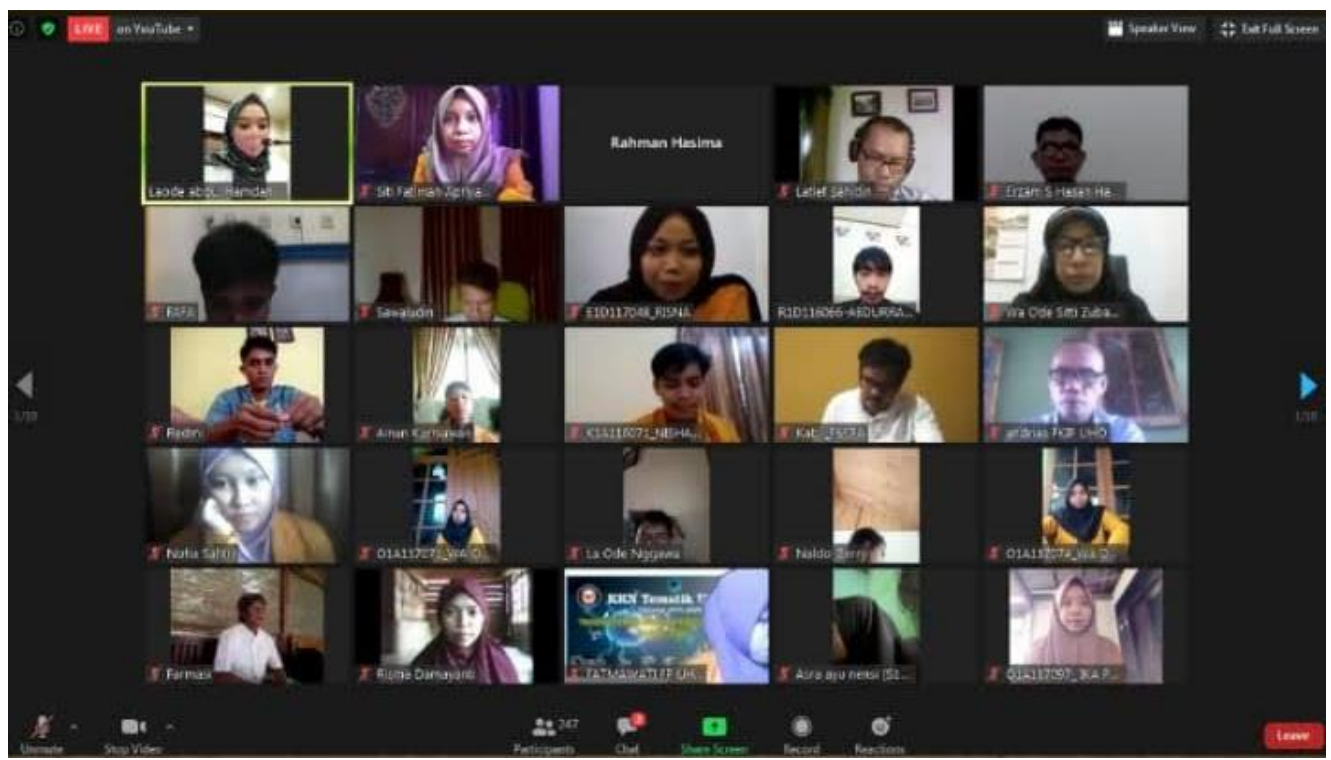

Gambar 1: Pertemuan awal antara dosen pembimbing lapangan (DPL) dengan mahasiswa peserta KKN Tematik secara online 
(2). Pelaksanaan, dilakukan dengan cara kunjungan ke lokasi secara bertahap, masing-masing 5-10 orang. Setiap kali turun ke lapangan masing-masing kelompok mengerjakan tugas sesuai arahan pada saat pertemuan awal, meliputi: Kelompok a, menyiapkan jaring keramba; Kelompok b, Memasang keramba; Kelompok c, menyiapkan dan menabur benih ikan; Kelompok d, menghitung anggaran. Setelah ikan di tabur, mahasiswa dijadwal secara bergantian untuk pemberian pakan dengan frekuensi 3 kali sehari (Amalia, et al. 2018). Setelah dua bulan, kegiatan pemberian pakan diambil alih oleh petugas kebersihan perumahan; (3). Pemanenan, dilakukan oleh petugas kebersihan pada bulan keempat. Selama waktu pelaksanaan program, dilakukan pula sosialisasi/penyuluhan kepada petugas kebersihan mengenai budidaya ikan dan pentingnya mengkonsumsi ikan bagi tubuh manusia

\section{HASIL DAN PEMBAHASAN}

Pada tahap persiapan mahasiswa sudah paham terhadap model KKN Tematik yang akan dilaksanakan, antara lain pemberlakukan protokol kesehatan. Berdasarkan tugas kelompok yang sudah dibagi, kelompok 1 dan II telah berhasil membuat jaring keramba dua buah masing-masing berukuran $3 \times 3 \times 3 \mathrm{~m}^{3}$ dan memasangnya di sungai (Gambar 2).
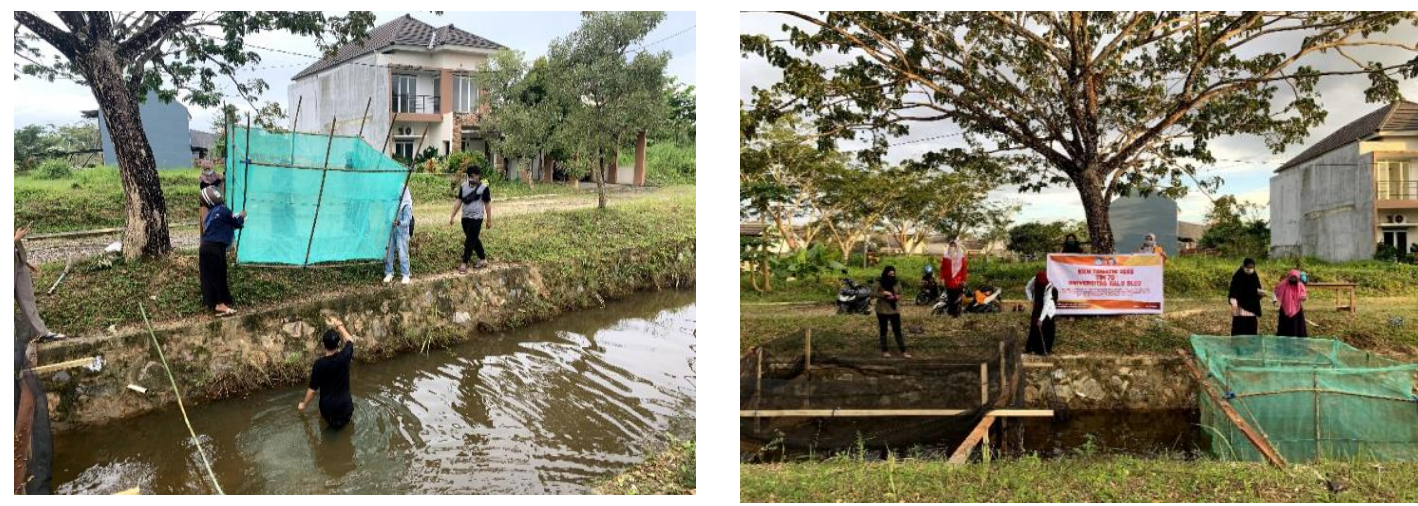

Gambar 2. Dua buah keramba yang berhasil dibuat dan dipasang oleh mahasiswa

Kelompok tiga, berhasil mengadakan benih ikan dan menaburnya ke dalam keramba, masingmasing 500 ekor ikan mujair dan 250 ekor ikan Nila (Oreochromis niloticus). Menurut Setianto (2012), ikan mujair merupakan salah satu sumber protein yang tinggi, mengandung asam lemak tak jenuh (omega-3, Eicosapentaenoic acid/EPA, Docosahexanoic acid/DHA) yang berfungsi untuk perkembangan otak. Pemilihan ikan nila karena budidayanya dapat dilakukan di tambak dan Karamba Jaring Apung (KJA) di perairan umum (Agustono, et al. 2009). Kelompok empat, menghitung seluruh pengeluaran dana, hasilnya adalah: Pasang dua buah keramba, @Rp. 1.000.000; Benih ikan, 500 ekor mujair Rp. 250.000,- 250 ekor Nila seharga Rp. 150.000,-; Kebutuhan pakan sebanyak 15 Kg seharga Rp. 282.000,--

Selama kegiatan KKN, mahasiswa sangat antusias untuk memahami pemanfaatan sungai untuk budidaya ikan. Hal lainnya adalah terbentuknya tim kerja yang kompak dikalangan mahasiswa. Diakhir program mahasiswa melakukan presentasi, menyusun laporan kegiatan, dan membuat video.

Setelah empat bulan dilakukan pemanenan, dan hasilnya diberikan kepada petugas kebersihan perumahan Tamansari Kahyangan Kendari. 


\section{KESIMPULAN}

1. Sebanyak 30 orang mahasiswa UHO telah mengikuti program pengabdian masyarakat terintegrasi KKN tematik semester genap 2019/2020 dengan program utama budidaya ikan air tawar di kompleks perumahan Tamansari Kahyangan Kendari.

2. Hasil budidaya ikan telah dibagikan kepada para petugas kebersihan perumahan Tamansari Kahyangan Kendari

\section{UCAPAN TERIMA KASIH}

Atas terlaksananya program pengabdian kepada masyarakat terintegrasi KKN Tematik tahun 2020, penulis mengucapkan terima kasih kepada : 1). UHO yang telah memberikan dana; 2). Pengelola Perumahan Tamansari Kahyangan atas izin yang diberikan

\section{DAFTAR PUSTAKA}

Agustono, Hadi M, Cahyoko Y. 2009. Pemberian tepung limbah udang yang difermentasi dalam ransum pakan buatan terhadap laju pertumbuhan, rasio konversi pakan dan kelangsungan hidup benih ikan nila (oreochromis niloticus), Jurnal IImiah Perikanan dan Kelautan, No. 2, Vol. 1, hal 157-162.

Rezkyana A, Amrullah, Suriati. 2018. Manajemen pemberian pakan pada pembesaran ikan nila (oreochromis niloticus), Prosiding Seminar Nasional, Sinergitas Multidisiplin IImu Pengetahuan dan Teknologi, Makasar, 9-10 April 2018.

Setianto, D. 2012. Budidaya Ikan Mujair di Berbagai Media Pemeliharaan. Pustaka Baru Press Yogyakarta. 